\title{
CETA: A win for Canada or European pharma?
}

$\mathrm{T}$ he day before the Canadian government hopes to clinch its Comprehensive Economic and Trade Agreement (CETA) with Europe at the Sept. 25 summit, opinion remains sharply divided on its cost implications for numerous medicines marketed by European pharmaceutical companies. CETA is the most ambitious trade deal ever between Canada and Europe, and pharmaceuticals are Europe's most valuable category of exports to Canada.

According to the government, in attempting to induce drug makers to invest in job-creating research by sweetening drug patents, Canadian negotiators carefully balanced patients' needs with its economic aims. But academic critics who've looked at official and unofficial texts of the deal disagree.

"It's a win for the brand-name drug makers," says Michael Geist, a University of Ottawa specialist on intellectual property law.

A technical summary of CETA released by Canadian trade negotiators in October 2013 revealed the deal's potential to substantially increase drug costs by extending patent protection for new drugs two years beyond the 20 years currently provided, delaying the introduction of lower-cost generic drugs.

The deal will also allow drug companies to sue Canada using a legal mechanism known as investor-state dispute settlement (ISDS), which relies on private arbitration tribunals rather than domestic courts. This also has the potential to inflict heavy costs. Using ISDS-type provisions in the North American Free Trade Agreement, Eli Lilly sued Canada for $\$ 500$ million in June 2013 over court rulings invalidating patents on drugs for schizophrenia and hyperactivity.

Canadian negotiators "woke up quite late" in opposing the entrenchment of arbitration tribunals within the ISDS mechanism, says Geist, and the European position won out. "Canada caved on its concern regarding pharma-

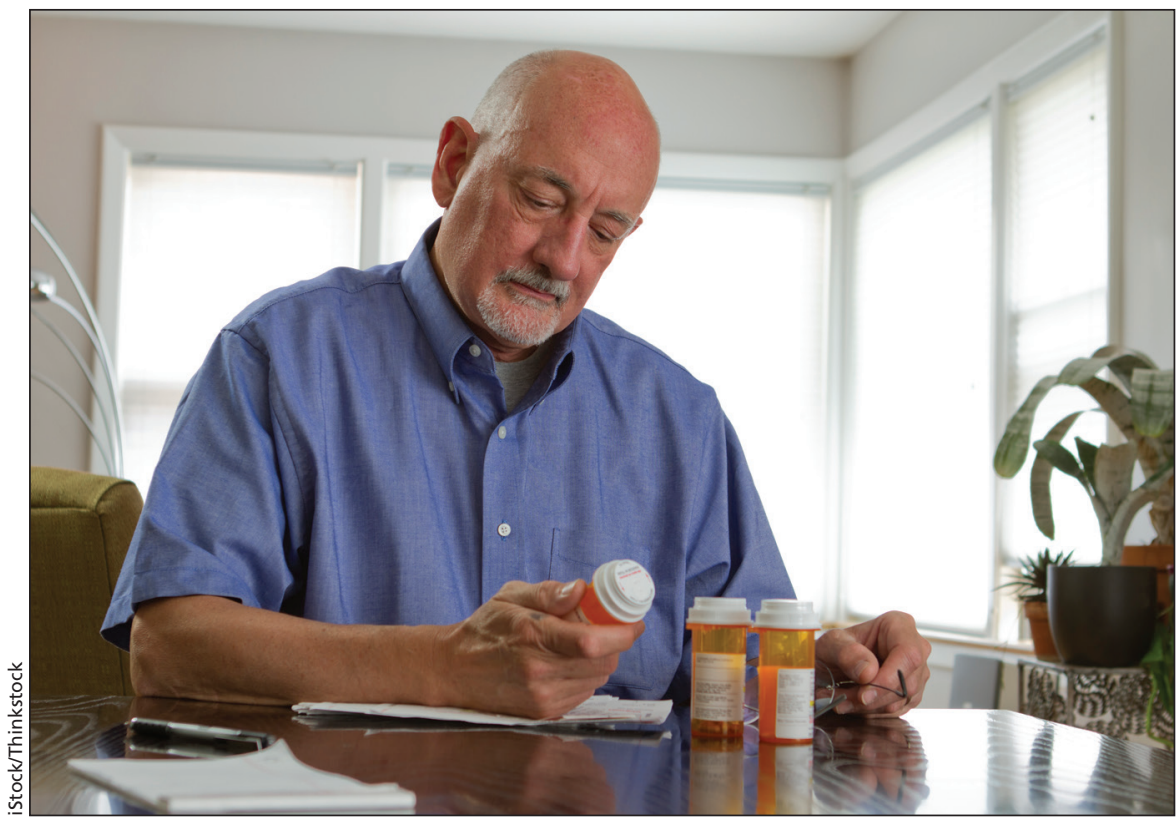

Canadians can expect to pay more for brand-name medications under the Comprehensive Economic and Trade Agreement, warn many health experts.

ceutical patent lawsuits that could potentially lead to claims with billions at stake."

Geist also believes the patent term extensions in CETA will lead to cost increases. The federal government acknowledged this possibility when it offered cash compensation to the provinces "for incremental increases in cost due to CETA," says Shannon Gutoskie, spokeswoman for federal Trade Minister Ed Fast.

But in agreeing to European demands for longer patents, the government has struck a balance between promoting drug development and job creation "and ensuring that Canadians continue to have access to the affordable drugs they need," says Gutoskie.

Canada's strategy, Gutoskie noted, is endorsed by a Conference Board of Canada study, funded with support from brand-name drug manufacturers, that argues "circumstantial evidence" from Europe suggests stronger intellectual property protection will encourage investment in new drug development in Canada.

CETA "likely will boost Canada's innovation ecosystem with minimal, if any, negative consequences," says the study's director, Dr. Gabriela Prada. European countries with patents longer than Canada's "have not seen drug prices increase faster than Canada over the last few years," she adds.

Any price increases stemming from longer patents may also be offset by price restrictions imposed by provincial drug insurance schemes and private insurers, says Prada. CETA "may not cause significant price inflation."

However, according to a study from the Canadian Centre for Policy Alternatives, CETA will force Canadians to pay $\$ 850$ million to $\$ 1.6$ billion more for patented drugs annually - a $7 \%$ to $13 \%$ increase on drug spending, which is already the second highest in the world per capita after the United States.

Much of the number-crunching behind these estimates was done by health economists, Aidan Hollis of the University of Calgary and Paul Grootendorst of the University of Toronto, in a 2011 study commissioned by the Canadian Generic Pharmaceutical Association (CGPA). 
"We concluded that payers - consumers, businesses, unions and government insurers - will face substantially higher drug costs as exclusivity is extended on top-selling prescription drugs," says Hollis.

The authors of both the CCPA and CGPA studies challenge the claim that extending patents encourages invest- ment in drug development. "The countries that are increasingly attracting pharmaceutical R\&D expenditures are emerging countries with much lower levels of patent protection," says Gagnon.

As for the government's pledge to compensate the provinces for the rise in drug costs, Gagnon suggests it will merely shift the burden onto federal taxpayers: "People paying for their drugs out-of-pocket or through private insurance, will be hit twice - through higher drug costs and their federal taxes." - Paul Christopher Webster, Toronto, Ont.

CMAJ 2014. DOI:10.1503/cmaj.109-4904 